\title{
The Impact of HMGB1 Polymorphisms on Prostate Cancer Progression and Clinicopathological Characteristics
}

\author{
Ying-Erh Chou ${ }^{1,2,3}$, Po-Jen Yang ${ }^{1,2,4}$, Chia-Yen Lin ${ }^{2,5}$, Yen-Yu Chen ${ }^{6}$, Whei-Ling Chiang ${ }^{7}$, \\ Pei-Xuan Lin ${ }^{7}$, Zih-Yun Huang ${ }^{7}$, Matthew Huang ${ }^{8}$, Yung-Chuan Ho ${ }^{3,6, *}$ \\ and Shun-Fa Yang 2,3,*(D) \\ 1 School of Medicine, Chung Shan Medical University, Taichung 402, Taiwan; intointo814@gmail.com (Y.-E.C.); \\ cshy1030@csh.org.tw (P.-J.Y.) \\ 2 Institute of Medicine, Chung Shan Medical University, Taichung 402, Taiwan; lcyhank.tw@gmail.com \\ 3 Department of Medical Research, Chung Shan Medical University Hospital, Taichung 402, Taiwan \\ 4 Department of Family and Community Medicine, Chung Shan Medical University Hospital, \\ Taichung 402, Taiwan \\ 5 Division of Urology, Department of Surgery, Taichung Veterans General Hospital, Taichung 407, Taiwan \\ 6 School of Medical Applied Chemistry, Chung Shan Medical University, Taichung 402, Taiwan; \\ ct511c3038@gmail.com \\ 7 School of Medical Laboratory and Biotechnology, Chung Shan Medical University, Taichung 402, Taiwan; \\ wlchiang@csmu.edu.tw (W.-L.C.); xuan87yte@gmail.com (P.-X.L.); forget0928240084@gmail.com (Z.-Y.H.) \\ 8 White Oaks Secondary School, Oakville, ON L6H 1Z5, Canada; Matthewh0304@gmail.com \\ * Correspondence: ych065@csmu.edu.tw (Y.-C.H.); ysf@csmu.edu.tw (S.-F.Y.)
}

Received: 26 August 2020; Accepted: 1 October 2020; Published: 3 October 2020

check for updates

\begin{abstract}
Prostate cancer is one of the major cancers of the genitourinary tract. High-mobility group box 1 (HMGB1) was suggested as a promising therapeutic target for prostate cancer. In this study, we aim to elucidate the associations of HMGB1 single nucleotide polymorphisms (SNPs) with prostate cancer susceptibility and clinicopathological characteristics. The HMGB1 SNPs rs1412125, rs2249825, rs1045411, and rs1360485 in 579 prostate cancer patients and 579 cancer-free controls were analyzed with real-time polymerase chain reactions (real-time PCR). All of the data were evaluated with SAS statistical software. Our results showed that the HMGB1 rs1045411 T allele genotype was significantly associated with advanced pathologic $\mathrm{T}$ stage (odds ratio $(\mathrm{OR})=1.433,95 \%$ confidence interval $(C I)=1.021-2.012 ; p=0.037)$ and pathologic N1 stage $(\mathrm{OR}=2.091,95 \% \mathrm{CI}=1.160-3.767 ; p=0.012)$, and the rs1360485 polymorphic CT + TT genotype was associated with pathologic Gleason grade group $(4+5)(\mathrm{OR}=1.583,95 \% \mathrm{CI}=1.017-2.462 ; p=0.041)$, pathologic $\mathrm{T}$ stage $(3+4)(\mathrm{OR}=1.482$, $95 \% \mathrm{CI}=1.061-2.070 ; p=0.021)$, and pathologic $\mathrm{N} 1$ stage $(\mathrm{OR}=2.131,95 \% \mathrm{CI}=1.178-3.852 ; p=0.011)$ compared with their wild-type carriers. In conclusion, our results revealed that the HMGB1 SNPS were associated with the clinical status of prostate cancer. The HMGB1 SNPs may have the potential to predict prostate cancer disease progression.
\end{abstract}

Keywords: prostate cancer; HMGB1; polymorphism

\section{Introduction}

Prostate cancer is the second most common cause of male malignancy worldwide [1,2]. In Taiwan, it is the fifth most common cancer, with the seventh-highest cancer-related mortality rate [3]. Aging and high-fat diets have been suggested as epidemiological risk factors that contribute to the rise of prostate cancer incidence in Taiwan [3,4]. Although androgen receptors (ARs) and the androgen signaling 
axis were the traditional focus for prostate cancer research and clinical therapy development [5-8], genome-wide assays have identified multiple highly penetrant genes (HPGs) and high-risk single nucleotide polymorphisms (SNPs) associated with prostate cancer risk in the prostate cancer-diagnosed genome [9-11].

High-mobility group box 1 (HMGB1) is a member of the HMG1-type polypeptides and acts as a DNA chaperone, sustaining nucleosome dynamics and chromosomal stability $[1,12,13]$. In prostate cancer, it was found that targeting HMGB1 with short hairpin RNA (shRNA) in prostate cancer cells leads to an inhibition of prostate cancer cell survival [14]. Overexpression of HMGB1 was observed to be significantly associated with poor biochemical recurrence (BCR)-free survival in patients after radical prostatectomy [15]. Moreover, HMGB1 was suggested as a novel target for potential therapeutics since highly expressed HMGB1 was found to be associated with the epithelial-to-mesenchymal transition (EMT) and the overexpression of MMP-1, MMP-3, and MMP-10 via the RAGE/NF- $\mathrm{kB}$ signaling pathways, facilitating prostate cancer metastasis [1,16-20]. Furthermore, polymorphisms of HMGB1 have been associated with many cancers, including oral squamous cell carcinoma (OSCC) [21,22], lung cancer [23-26], breast cancer [27-29], gastric cancer [30], hepatocellular carcinoma (HCC) [31,32], and colorectal cancer (CRC) [33], and it was suggested that the SNPs of HMGB1 may provide a potential biomarker for predicting cancer risk, tumor development, or chemotherapy responses [21,25,27,31]. However, the impact of $H M G B 1$ polymorphisms on prostate cancer susceptibility and clinicopathologic characteristics has remained uninvestigated. In this study, we focus on four SNPs of HMGB1, rs1412125, rs2249825, rs1045411, rs1360485, and try to elucidate their associations with prostate cancer susceptibility and clinicopathologic characteristics.

\section{Materials and Methods}

\subsection{Study Subjects}

In this study, we enrolled 579 patients with prostate cancer as the study group. These patients received robot-assisted radical prostatectomy at Taichung Veteran General Hospital from 2012 to 2017. At the same time, 579 individuals who entered the hospital for a physical examination were selected from the physical examination center to serve as the control group. The control groups were generally healthy without a cancer history and without diseases related to the vital organs according to routine laboratory tests. Participants' personal characteristics and information, including age, gender, and medical histories, were obtained using interviewer-administered questionnaires. The study was certified by the Institutional Review Broad (IRB) of Taichung Veteran General Hospital, and informed consent was collected from each individual involved in this study (IRB No. CE19062A). Medical information including age at diagnosis, initial prostate specific antigen (PSA) level at diagnosis, pathologic Gleason grade group, clinical and pathological TNM staging, seminal vesicle invasion, perineural invasion, lymphovascular invasion, and D'Amico classification were acquired from each patient's medical records [34-37]. In this study, the Gleason grade group and D'Amico classification were grouped according to the International Society of Urological Pathology (ISUP) consensus in 2016 [38].

\subsection{Sample Preparation and DNA Extraction}

The blood specimens were collected from patients with prostate cancer and normal controls involved in our study. The peripheral whole blood samples were preserved in EDTA-containing tubes, followed with centrifugation at a setting of $3000 \mathrm{rpm}$ for $10 \mathrm{~min}$. To collect the DNA, we performed a DNA extraction assay by using QIAamp DNA blood kits. All the protocols of DNA extraction was performed according to the instructions in the manufacturer's manual $[39,40]$. The final extracted DNA was applied as a DNA template in the polymerase chain reaction (PCR) assay. 


\subsection{Selection of HMGB1 SNPS}

In this study, four SNPs of HMGB1, rs1412125 (in the promoter region), rs2249825 (intron 1), rs1045411 (3’UTR), and rs1360485 (3’UTR), were selected from the Single Nucleotide Polymorphism Database (dbSNP) [41]. The SNP rs1412125 of HMGB1 was selected because the rs1412125 polymorphism was suggested to be associated with pneumonia susceptibility, severity, and inflammatory response [42]. For HMGB1 rs1360485, patients with one C allele in the rs1360485 domain were suggested to be at greater risk of developing $\mathrm{T} 2$ tumors and lymph node metastasis in breast cancer [27]. The SNP rs1045411 of HMGB1 was selected because it was observed that rs 1045411 was correlated with a significant effect on HMGB1 expression, and was significantly associated with clinical outcomes, especially in Chinese gastric cancer patients with aggressive status after surgery [30].

\subsection{HMGB1 SNPs Genotyping}

The HMGB1 rs1412125, rs2249825, rs1045411 and rs1360485 SNPs were assayed by using quantitative real-time PCR (qRT-PCR) with an ABI StepOne Real-Time PCR system (Applied Biosystems, Foster City, CA, USA). All the PCR primers and Taqman probes were designed by the same company (assay ID C_8690889_10 for rs1412125; C_15815760_10 for rs2249825; C_3025198_30 for rs1045411; and C_8690872_10 for rs1360485).

\subsection{Statistical Analyses}

To compare the age between controls and the patients with prostate cancer, a Student's $t$-test was performed. The adjusted odds ratios (AORs) with 95\% confidence intervals (CIs) were estimated using a multivariable logistic model after adjusting for age to determine the distribution frequency of HMGB1 genotypes between control group and prostate cancer patients. For estimating the odds ratio (OR) of the association between the HMGB1 SNPs and prostate cancer risk, logistic regression models were adopted for data analysis and evaluation. All of the data in our study were evaluated with SAS statistical software. A value of $p<0.05$ was considered to represent statistical significance, with * standing for $p<0.05,{ }^{* *}$ indicating $p<0.01$, and ${ }^{* * *}$ meaning $p<0.001$.

\section{Results}

The distribution of demographic characteristics in 579 control individuals and 579 patients with prostate cancer is given in Table 1. In the current study, we observed that the distribution of age at diagnosis (>60 years) was $25.7 \%$ (149/579) of the controls and $82.6 \%(478 / 579)$ of the patients with prostate cancer. Two hundred and seventy patients (46.6\%) had high PSA levels (PSA $>10 \mathrm{ng} / \mathrm{mL}$ ), and the median level was $10.54 \mathrm{ng} / \mathrm{mL}$ (range 0.634-685). A significant distributional difference was found for age at diagnosis ( $>60$ years) between the controls and patients with prostate cancer $(p<0.001)$.

The distribution frequency of HMGB1 genotypes in 579 control individuals and 579 patients with prostate cancer is given in Table 2. To diminish the possible interference of age, the adjusted odds ratios (AORs) with $95 \%$ CIs were estimated by multiple logistic regression models after controlling for age in each comparison. As shown in Table 2, no significant difference was observed for patients with prostate cancer among the rs1412125, rs2249825, rs1045411, and rs1360485 polymorphisms of the HMGB1 gene and those with the wild-type (WT) gene in the pre- and post-adjustment for age (Table 2). 
Table 1. The distributions of demographical characteristics in 579 control individuals and 579 patients with prostate cancer.

\begin{tabular}{|c|c|c|c|}
\hline Variable & Controls $(n=579)(\%)$ & Patients $(n=579)(\%)$ & $p$-Value \\
\hline \multicolumn{4}{|l|}{ Age at diagnosis (years) } \\
\hline$\leq 60$ & $430(74.3 \%)$ & $101(17.4 \%)$ & $p<0.001$ \\
\hline$>60$ & $149(25.7 \%)$ & $478(82.6 \%)$ & \\
\hline Mean \pm S.D. & $52.31 \pm 10.08$ & $67.08 \pm 7.42$ & $p<0.001$ \\
\hline \multicolumn{4}{|c|}{ PSA at diagnosis $(\mathrm{ng} / \mathrm{mL})$} \\
\hline$\leq 10$ & & 309 (53.4\%) & \\
\hline$>10$ & & $270(46.6 \%)$ & \\
\hline \multicolumn{4}{|c|}{ Pathologic Gleason grade group } \\
\hline $1+2+3$ & & $484(83.6 \%)$ & \\
\hline $4+5$ & & $95(16.4 \%)$ & \\
\hline \multicolumn{4}{|l|}{ Clinical T stage } \\
\hline $1+2$ & & $501(86.5 \%)$ & \\
\hline $3+4$ & & $78(13.5 \%)$ & \\
\hline \multicolumn{4}{|l|}{ Pathologic T stage } \\
\hline 2 & & $306(52.8 \%)$ & \\
\hline $3+4$ & & $273(47.2 \%)$ & \\
\hline \multicolumn{4}{|l|}{ Pathologic N stage } \\
\hline No & & $530(91.5 \%)$ & \\
\hline N1 & & $49(8.5 \%)$ & \\
\hline \multicolumn{4}{|c|}{ Seminal vesicle invasion } \\
\hline No & & $452(78.1 \%)$ & \\
\hline Yes & & $127(21.9 \%)$ & \\
\hline \multicolumn{4}{|l|}{ Perineural invasion } \\
\hline No & & $155(26.8 \%)$ & \\
\hline Yes & & $424(73.2 \%)$ & \\
\hline \multicolumn{4}{|c|}{ Lymphovascular invasion } \\
\hline No & & $482(83.2 \%)$ & \\
\hline Yes & & $97(16.8 \%)$ & \\
\hline \multicolumn{4}{|c|}{ D'Amico classification } \\
\hline Low risk & & $60(10.4 \%)$ & \\
\hline Intermediate risk & & $220(38.0 \%)$ & \\
\hline High risk & & $299(51.6 \%)$ & \\
\hline
\end{tabular}

Table 2. Distribution frequency of high-mobility group box 1 (HMGB1) genotypes in 579 control individuals and 579 patients with prostate cancer.

\begin{tabular}{ccccc}
\hline Variables & Controls $(\boldsymbol{n}=\mathbf{5 7 9 )} \mathbf{( \% )}$ & Patients $(\boldsymbol{n = 5 7 9 )} \mathbf{( \% )}$ & OR (95\% CI) + & AOR (95\% CI) $\ddagger$ \\
\hline rs1412125 & & & & \\
TT & $318(54.9 \%)$ & $333(57.5 \%)$ & 1.00 & 1.00 \\
TC & $222(38.3 \%)$ & $209(36.1 \%)$ & $0.899(0.705-1.147)$ & $0.757(0.562-1.021)$ \\
CC & $39(6.8 \%)$ & $37(6.4 \%)$ & $0.906(0.563-1.457)$ & $0.626(0.354-1.108)$ \\
TC + CC & $261(45.1 \%)$ & $246(42.5 \%)$ & $0.900(0.714-1.135)$ & $0.848(0.649-1.107)$ \\
\hline rs2249825 & & & & \\
CC & $431(74.4 \%)$ & $438(75.6 \%)$ & 1.00 & 1.00 \\
CG & $139(24.0 \%)$ & $126(21.8 \%)$ & $0.892(0.677-1.175)$ & $0.820(0.587-1.146)$ \\
GG & $9(1.6 \%)$ & $15(2.6 \%)$ & $1.640(0.710-3.788)$ & $1.785(0.647-4.925)$ \\
CG + GG & $148(25.6 \%)$ & $141(24.4 \%)$ & $0.937(0.718-1.223)$ & $0.874(0.632-1.208)$ \\
\hline rs1045411 & & & & \\
CC & $353(61.0 \%)$ & $367(63.4 \%)$ & 1.00 & 1.00 \\
CT & $200(34.5 \%)$ & $186(32.1 \%)$ & $0.895(0.698-1.146)$ & $0.887(0.656-1.199)$ \\
TT & $26(4.5 \%)$ & $26(4.5 \%)$ & $0.962(0.548-1.689)$ & $0.847(0.429-1.672)$ \\
CT + TT & $226(39.0 \%)$ & $212(36.6 \%)$ & $0.902(0.711-1.144)$ & $0.882(0.661-1.178)$ \\
\hline rs1360485 & & & & \\
TT & $335(57.9 \%)$ & $347(59.9 \%)$ & 1.00 & 1.00 \\
TC & $211(36.4 \%)$ & $199(34.4 \%)$ & $0.911(0.713-1.163)$ & $0.900(0.668-1.213)$ \\
CC & $33(5.7 \%)$ & $33(5.7 \%)$ & $0.965(0.582-1.600)$ & $0.897(0.486-1.657)$ \\
TC + CC & $244(42.1 \%)$ & $232(40.1 \%)$ & $0.918(0.726-1.160)$ & $0.899(0.676-1.196)$ \\
\hline
\end{tabular}

† The odds ratios (ORs) with their 95\% confidence intervals were estimated by logistic regression models. $\ddagger$ The adjusted odds ratios (AORs) with their $95 \%$ confidence intervals were estimated by multiple logistic regression models after controlling for age. 
To clarify the role of $H M G B 1$ genetic polymorphisms in prostate cancer status, the clinical status and HMGB1 genotype frequencies in 579 prostate cancer patients were assessed (Tables 3-5). For HMGB1 rs1412125, the HMGB1 rs1412125 polymorphic TC + CC genotypic variant was significantly associated with a higher $\mathrm{D}^{\prime}$ Amico classification $(\mathrm{OR}=1.405,95 \% \mathrm{CI}=1.009-1.956 ; p=0.044)$ compared with the TT genotype in 579 patients with prostate cancer (Table 3). The HMGB1 rs1045411 polymorphic $\mathrm{CT}+\mathrm{TT}$ genotype was significantly associated with advanced pathologic stage $(\mathrm{OR}=1.433$, $95 \% \mathrm{CI}=1.021-2.012 ; p=0.037)$ and pathologic $\mathrm{N} 1$ stage $(\mathrm{OR}=2.091,95 \% \mathrm{CI}=1.160-3.767 ; p=0.012)$ compared to the wild-type carriers (Table 4). Moreover, the rs1360485 polymorphic TC + CC genotype was associated with the pathologic Gleason grade $4+5$ group $(\mathrm{OR}=1.583,95 \% \mathrm{CI}=1.017-2.462$; $p=0.041)$, pathologic $\mathrm{T} 3+\mathrm{T} 4$ stage $(\mathrm{OR}=1.482,95 \% \mathrm{CI}=1.061-2.070 ; p=0.021)$, and pathologic $\mathrm{N} 1$ stage (OR $=2.131,95 \% \mathrm{CI}=1.178-3.852 ; p=0.011)$ compared with the wild-type carriers (Table 5). However, no significant association was found between the HMGB1 rs2249825 SNPs and clinical status in 579 prostate cancer patients (data not shown).

Table 3. Odds ratios (ORs) and 95\% confidence intervals (CIs) of clinical status and HMGB1 rs1412125 genotypic frequencies in 579 patients with prostate cancer.

\begin{tabular}{|c|c|c|c|c|}
\hline \multirow{2}{*}{$\begin{array}{c}\text { Variable } \\
\text { rs1412125 }\end{array}$} & \multicolumn{4}{|c|}{ Genotypic Frequencies } \\
\hline & TT $(N=333)$ & $\mathrm{TC}+\mathrm{CC}(N=246)$ & OR $(95 \% \mathrm{CI})$ & $p$-Value \\
\hline \multicolumn{5}{|l|}{ PSA at diagnosis $(\mathrm{ng} / \mathrm{mL})$} \\
\hline$\leq 10$ & $151(45.3 \%)$ & $119(48.4 \%)$ & 1.00 & $p=0.470$ \\
\hline$>10$ & $182(54.7 \%)$ & $127(51.6 \%)$ & $0.885(0.636-1.232)$ & \\
\hline \multicolumn{5}{|c|}{ Pathologic Gleason grade group } \\
\hline $1+2+3$ & $282(84.7 \%)$ & $202(82.1 \%)$ & 1.00 & $p=0.409$ \\
\hline $4+5$ & $51(15.3 \%)$ & $44(17.9 \%)$ & $1.204(0.774-1.874)$ & \\
\hline \multicolumn{5}{|l|}{ Clinical T stage } \\
\hline $1+2$ & $284(85.3 \%)$ & $217(88.2 \%)$ & 1.00 & $p=0.308$ \\
\hline $3+4$ & $49(14.7 \%)$ & $29(11.8 \%)$ & $0.775(0.474-1.267)$ & \\
\hline \multicolumn{5}{|l|}{ Pathologic T stage } \\
\hline 2 & $183(55.0 \%)$ & $123(50.0 \%)$ & 1.00 & $p=0.238$ \\
\hline $3+4$ & $150(45.0 \%)$ & $123(50.0 \%)$ & $1.220(0.877-1.697)$ & \\
\hline \multicolumn{5}{|l|}{ Pathologic N stage } \\
\hline No & $307(92.2 \%)$ & $223(90.7 \%)$ & 1.00 & $p=0.510$ \\
\hline N1 & $26(7.8 \%)$ & $23(9.3 \%)$ & $1.218(0.677-2.190)$ & \\
\hline \multicolumn{5}{|l|}{ Seminal vesicle invasion } \\
\hline No & $260(78.1 \%)$ & $192(78.0 \%)$ & 1.00 & $p=0.993$ \\
\hline Yes & $73(21.9 \%)$ & $54(22.0 \%)$ & $1.002(0.673-1.492)$ & \\
\hline \multicolumn{5}{|l|}{ Perineural invasion } \\
\hline No & $88(26.4 \%)$ & $67(27.2 \%)$ & 1.00 & $p=0.828$ \\
\hline Yes & $245(73.6 \%)$ & $179(72.8 \%)$ & $0.960(0.662-1.392)$ & \\
\hline \multicolumn{5}{|l|}{ Lymphovascular invasion } \\
\hline No & $282(84.7 \%)$ & $200(81.3 \%)$ & 1.00 & $p=0.281$ \\
\hline Yes & $51(15.3 \%)$ & $46(18.7 \%)$ & $1.272(0.821-1.970)$ & \\
\hline \multicolumn{5}{|l|}{ D'Amico classification } \\
\hline Low/Intermediate risk & $173(52.0 \%)$ & $107(43.5 \%)$ & 1.00 & $p=0.044 *$ \\
\hline High risk & $160(48.0 \%)$ & $139(56.5 \%)$ & 1.405 (1.009-1.956) & \\
\hline
\end{tabular}

The ORs and their $95 \%$ CIs were estimated by logistic regression models. ${ }^{*} p$-value $<0.05=$ statistically significant.

Table 4. Odds ratios (ORs) and 95\% confidence intervals (CIs) of clinical status and HMGB1 rs1045411 genotypic frequencies in 579 patients with prostate cancer.

\begin{tabular}{ccccc}
\hline Variable & \multicolumn{4}{c}{ Genotypic Frequencies } \\
\hline rs1045411 & CC $(\boldsymbol{N}=\mathbf{3 6 7})$ & $\mathrm{CT}+$ TT $(\boldsymbol{N}=\mathbf{2 1 2})$ & OR $\mathbf{( 9 5 \%} \mathbf{C I})$ & $p$-Value \\
\hline PSA at diagnosis $(\mathbf{n g} / \mathrm{mL})$ & & & & \\
$\leq 10$ & $167(45.5 \%)$ & $103(48.6 \%)$ & 1.00 & $p=0.474$ \\
$>10$ & $200(54.5 \%)$ & $109(51.4 \%)$ & $0.884(0.630-1.240)$ & \\
\hline
\end{tabular}


Table 4. Cont

\begin{tabular}{|c|c|c|c|c|}
\hline \multirow{2}{*}{$\begin{array}{c}\text { Variable } \\
\text { rs1045411 }\end{array}$} & \multicolumn{4}{|c|}{ Genotypic Frequencies } \\
\hline & $\mathrm{CC}(N=367)$ & $\mathrm{CT}+\mathrm{TT}(N=212)$ & OR $(95 \% \mathrm{CI})$ & $p$-Value \\
\hline \multicolumn{5}{|c|}{ Pathologic Gleason grade group } \\
\hline $1+2+3$ & $314(85.6 \%)$ & $170(80.2 \%)$ & 1.00 & $p=0.093$ \\
\hline $4+5$ & $53(14.4 \%)$ & $42(19.8 \%)$ & $1.464(0.937-2.286)$ & \\
\hline \multicolumn{5}{|l|}{ Clinical T stage } \\
\hline $1+2$ & $321(87.5 \%)$ & $180(84.9 \%)$ & 1.00 & $p=0.385$ \\
\hline $3+4$ & $46(12.5 \%)$ & $32(15.1 \%)$ & $1.241(0.763-2.018)$ & \\
\hline \multicolumn{5}{|l|}{ Pathologic T stage } \\
\hline 2 & $206(56.1 \%)$ & $100(47.2 \%)$ & 1.00 & $p=0.037 *$ \\
\hline $3+4$ & $161(43.9 \%)$ & $112(52.8 \%)$ & $1.433(1.021-2.012)$ & \\
\hline \multicolumn{5}{|l|}{ Pathologic N stage } \\
\hline No & $344(93.7 \%)$ & $186(87.7 \%)$ & 1.00 & $p=0.012 *$ \\
\hline N1 & $23(6.3 \%)$ & $26(12.3 \%)$ & $2.091(1.160-3.767)$ & \\
\hline \multicolumn{5}{|l|}{ Seminal vesicle invasion } \\
\hline No & $294(80.1 \%)$ & $158(74.5 \%)$ & 1.00 & $p=0.118$ \\
\hline Yes & $73(19.9 \%)$ & $54(25.5 \%)$ & $1.376(0.921-2.056)$ & \\
\hline \multicolumn{5}{|l|}{ Perineural invasion } \\
\hline No & $103(28.1 \%)$ & $52(24.5 \%)$ & 1.00 & $p=0.354$ \\
\hline Yes & $264(71.9 \%)$ & $160(75.5 \%)$ & $1.200(0.815-1.768)$ & \\
\hline \multicolumn{5}{|l|}{ Lymphovascular invasion } \\
\hline No & $312(85.0 \%)$ & $170(80.2 \%)$ & 1.00 & $p=0.134$ \\
\hline Yes & $55(15.0 \%)$ & $42(19.8 \%)$ & $1.401(0.900-2.183)$ & \\
\hline \multicolumn{5}{|l|}{ D'Amico classification } \\
\hline Low/Intermediate risk & $187(51.0 \%)$ & $93(43.9 \%)$ & 1.00 & $p=0.100$ \\
\hline High risk & $180(49.0 \%)$ & $119(56.1 \%)$ & $1.329(0.946-1.867)$ & \\
\hline
\end{tabular}

The ORs and their $95 \%$ CIs were estimated by logistic regression models. ${ }^{*} p$-value $<0.05=$ statistically significant.

Table 5. Odds ratios (ORs) and 95\% confidence intervals (CIs) of clinical status and HMGB1 rs1360485 genotypic frequencies in 579 patients with prostate cancer.

\begin{tabular}{|c|c|c|c|c|}
\hline \multirow{2}{*}{$\begin{array}{c}\text { Variable } \\
\text { rs1360485 } \\
\end{array}$} & \multicolumn{4}{|c|}{ Genotypic Frequencies } \\
\hline & $\mathrm{TT}(N=347)$ & $\mathrm{TC}+\mathrm{CC}(N=232)$ & OR $(95 \% \mathrm{CI})$ & $p$-Value \\
\hline \multicolumn{5}{|l|}{ PSA at diagnosis $(\mathrm{ng} / \mathrm{mL})$} \\
\hline$\leq 10$ & $161(46.4 \%)$ & $109(47.0 \%)$ & 1.00 & \multirow[t]{2}{*}{$p=0.890$} \\
\hline$>10$ & $186(53.6 \%)$ & $123(53.0 \%)$ & $0.977(0.700-1.363)$ & \\
\hline \multicolumn{5}{|c|}{ Pathologic Gleason grade group } \\
\hline $1+2+3$ & $299(86.2 \%)$ & $185(79.7 \%)$ & 1.00 & \multirow{2}{*}{$p=0.041$ * } \\
\hline $4+5$ & $48(13.8 \%)$ & $47(20.3 \%)$ & $1.583(1.017-2.462)$ & \\
\hline \multicolumn{5}{|l|}{ Clinical T stage } \\
\hline $1+2$ & $302(87.0 \%)$ & $199(85.8 \%)$ & 1.00 & \multirow[t]{2}{*}{$p=0.664$} \\
\hline $3+4$ & $45(13.0 \%)$ & $33(14.2 \%)$ & $1.113(0.686-1.805)$ & \\
\hline \multicolumn{5}{|l|}{ Pathologic T stage } \\
\hline 2 & $197(56.8 \%)$ & $109(47.0 \%)$ & 1.00 & \multirow[t]{2}{*}{$p=0.021$ * } \\
\hline $3+4$ & $150(43.2 \%)$ & $123(53.0 \%)$ & $1.482(1.061-2.070)$ & \\
\hline \multicolumn{5}{|l|}{ Pathologic N stage } \\
\hline No & $326(93.9 \%)$ & $204(87.9 \%)$ & 1.00 & \multirow[t]{2}{*}{$p=0.011$ * } \\
\hline N1 & $21(6.1 \%)$ & $28(12.1 \%)$ & $2.131(1.178-3.852)$ & \\
\hline \multicolumn{5}{|l|}{ Seminal vesicle invasion } \\
\hline No & $279(80.4 \%)$ & $173(74.6 \%)$ & 1.00 & \multirow[t]{2}{*}{$p=0.096$} \\
\hline Yes & $68(19.6 \%)$ & $59(25.4 \%)$ & $1.399(0.941-2.081)$ & \\
\hline \multicolumn{5}{|l|}{ Perineural invasion } \\
\hline No & $97(28.0 \%)$ & $58(25.0 \%)$ & 1.00 & \multirow[t]{2}{*}{$p=0.431$} \\
\hline Yes & $250(72.0 \%)$ & $174(75.0 \%)$ & $1.164(0.797-1.700)$ & \\
\hline \multicolumn{5}{|l|}{ Lymphovascular invasion } \\
\hline No & $296(85.3 \%)$ & $186(80.2 \%)$ & 1.00 & \multirow{2}{*}{$p=0.105$} \\
\hline Yes & $51(14.7 \%)$ & $46(19.8 \%)$ & $1.435(0.926-2.226)$ & \\
\hline \multicolumn{5}{|l|}{ D'Amico classification } \\
\hline Low/Intermediate risk & $178(51.3 \%)$ & $102(44.0 \%)$ & 1.00 & \multirow[t]{2}{*}{$p=0.084$} \\
\hline High risk & $169(48.7 \%)$ & $130(56.0 \%)$ & $1.342(0.961-1.875)$ & \\
\hline
\end{tabular}

The ORs and their 95\% CIs were estimated by logistic regression models. ${ }^{*} p$-value $<0.05=$ statistically significant. 


\section{Discussion}

In this study, we demonstrated the associations between HMGB1 polymorphisms and prostate cancer. Many risk factors, including age, the concentration of prostate-specific antigen (PSA), family history, insulin-like growth factors, ethnicity, obesity, alcohol consumption, sexually transmitted disease, vasectomy, and smoking, were suggested to be associated with prostate cancer risk [43]. As to the correlations of age and PSA levels with prostate cancer risk, previous studies have suggested that, from the age of 60 , the concentration of PSA predicts the lifetime risk of metastasis and death from prostate cancer [43-45]. In our study, $478(82.6 \%)$ of 579 prostate cancer patients were diagnosed at age $>60(p<0.001$, Table 1$)$, while more of the patients involved in our study had a PSA level at diagnosis of $\leq 10 \mathrm{ng} / \mathrm{mL}$ ( $53.4 \%$, Table 1$)$. Therefore, it seems that age $>60$ is a more dominant risk factor for those individuals involved in our study.

We further examined the associations between HMGB1 polymorphisms and prostate cancer susceptibility. However, no significant associations were found among HMGB1 rs1412125, rs2249825, rs1045411, rs1360485, and prostate cancer (Table 2), suggesting that the direct impact of HMGB1 SNPs on prostate cancer susceptibility might be limited. Intriguingly, after we analyzed the associations of clinical status and these HMGB1 SNPs, we found that the HMGB1 rs1412125 polymorphic variants were associated with a higher D'Amico classification ( $p=0.044$, Table 3). Moreover, the HMGB1 rs1045411 genetic variant $\mathrm{CT}+\mathrm{TT}$ genotype was found to have statistically significant associations in pathologic T stage (stage $3+4, p=0.037$ ) and pathologic $\mathrm{N}$ stage (stage N1, $p=0.012$ ) compared with the wild-type carriers (Table 4). Similar results were also observed in HMGB1 rs1360485, while HMGB1 rs1360485 $\mathrm{TC}+\mathrm{CC}$ polymorphic variants were found to have statistically significant associations with pathologic Gleason grade (group $4+5, p=0.041$ ), pathologic T stage (stage $3+4, p=0.021$ ), and pathologic $\mathrm{N}$ stage (stage N1, $p=0.011$ ) compared to their wild-type carriers (Table 5). Taken together, these results suggested that the SNPs of HMGB1 might play a more crucial role in tumor progression than carcinogenesis and cancer susceptibility in prostate cancer.

The role of HMGB1 SNPs in cancer risk, disease progression, and tumor development remains controversial. Some studies have associated HMGB1 SNPs with increased cancer risk, disease susceptibility, severity, and progression, or poorer response to treatment [22,23,27,31,33,42,46-49]. However, other studies have indicated that the HMGB1 SNPs are associated with a lower risk of cancer and a less invasive disease [26,50], or may even not be associated with the risk of cancer [51]. Of note, no information on HMGB1 polymorphisms and prostate cancer risk was mentioned or discussed in the meta-analysis conducted by Li et al. [51], so the correlations of HMGB1 SNPs with prostate cancer risk and disease progression remain uncertain. We found no statistically significant association between the HMGB1 polymorphic variants and prostate cancer patients, implying that the direct impact of HMGB1 SNPs on prostate cancer susceptibility might be limited (Table 2). However, the results of our study have demonstrated that the HMGB1 polymorphisms rs1412125, rs1045411, and rs1360485 were associated with prostate cancer disease progression and severity (Tables 3-5), suggesting more consistency of HMGB1 SNPs in the oncogenicity of various cancers. In contrast, we found that the HMGB1 rs2249825 polymorphic variants showed no significant association with prostate cancer susceptibility (Table 2) or the clinical status of prostate cancer, suggesting a difference from colorectal cancer [33] and cervical cancer [47]. Besides, our previous study found that urothelial cell carcinoma (UCC) patients who carry at least one T allele of the HMGB1 rs1045411 polymorphism had a lower risk and less invasive disease [50]. However, in our current study, the HMGB1 rs1045411 polymorphic variants were associated with advanced pathologic T stage $(p=0.037)$ and pathologic N1 stage $(p=0.012)$ in prostate cancer patients (Table 4$)$. One possible reason for this phenomenon is that rs1045411 is located in the $3^{\prime}$ untranslated region of HMGB1, which is the most sensitive region to microRNA epigenetic regulation [50]. Thus, the increased susceptibility of malignant progression might result from HMGB1 mRNA instability [30,50,52]. Taken together, these results exhibit the variety of HMGB1 SNPs in different cancers, consistent with the oncogenic and tumor-suppressing dual roles of HMGB1 during tumor development and therapy [13]. Different ethnicities, epigenetic factors, 
or genetic susceptibility might be responsible for this phenomenon [53,54]. A limitation of our study is that we lack data on HMGB1 mRNA or protein expression in prostate cancer patients, so more detailed analyses and evaluations could not be performed.

\section{Conclusions}

In conclusion, our study demonstrated that the HMGB1 SNPs were associated with prostate cancer progression and development. Patients who carried the HMGB1 rs1412125, rs1045411, and rs1360485 polymorphic variants were associated with a poorer prognosis of prostate cancer, including a higher D'Amico classification, higher pathologic Gleason grade group, higher pathologic $\mathrm{T}$ stage, and higher pathologic $\mathrm{N}$ stage. The HMGB1 polymorphisms may serve as a predictor of prostate cancer development and tumor progression.

Author Contributions: Conceptualization, Y.-E.C., P.-J.Y., Y.-C.H., and S.-F.Y.; methodology, Y.-Y.C., P.-X.L., Z.-Y.H., and M.H.; formal analysis, Y.-E.C., W.-L.C., and S.-F.Y.; resources, C.-Y.L.; writing-original draft preparation, Y.-E.C., P.-J.Y., and S.-F.Y.; writing-review and editing, Y.-E.C., Y.-C.H., and S.-F.Y. All authors have read and agreed to the published version of the manuscript.

Funding: This research received no external funding.

Conflicts of Interest: The authors declare no conflict of interest.

\section{References}

1. Lv, D.J.; Song, X.L.; Huang, B.; Yu, Y.Z.; Shu, F.P.; Wang, C.; Chen, H.; Zhang, H.B.; Zhao, S.C. Hmgb1 promotes prostate cancer development and metastasis by interacting with brahma-related gene 1 and activating the akt signaling pathway. Theranostics 2019, 9, 5166-5182. [CrossRef]

2. Siegel, R.L.; Miller, K.D.; Jemal, A. Cancer statistics, 2018. CA Cancer J. Clin. 2018, 68, 7-30. [CrossRef]

3. Hung, C.F.; Yang, C.K.; Ou, Y.C. Urologic cancer in Taiwan. Jpn. J. Clin. Oncol. 2016, 46, 605-609. [CrossRef]

4. Pu, Y.S. Prostate cancer in Taiwan: Epidemiology and risk factors. Int. J. Androl. 2000, 23, 34-36. [CrossRef]

5. Dai, C.; Heemers, H.; Sharifi, N. Androgen signaling in prostate cancer. Cold Spring Harb. Perspect. Med. 2017, 7, a030452. [CrossRef]

6. Schreyer, E.; Barthelemy, P.; Cottard, F.; Ould Madi-Berthelemy, P.; Schaff-Wendling, F.; Kurtz, J.E.; Ceraline, J. Androgen receptor variants in prostate cancer. Med. Sci. M/S 2017, 33, 758-764.

7. McAllister, M.J.; McCall, P.; Dickson, A.; Underwood, M.A.; Andersen, D.; Holmes, E.; Markert, E.; Leung, H.Y.; Edwards, J. Androgen receptor phosphorylation at serine 81 and serine 213 in castrate-resistant prostate cancer. Prostate Cancer Prostatic Dis. 2020, in press. [CrossRef] [PubMed]

8. Lu, Y.C.; Huang, C.Y.; Yeh, H.M.; Hong, J.H.; Chang, C.H.; Muo, C.H.; Chung, S.D.; Yang, T.K.; Jaw, F.S.; Chung, C.J. Associations between peripheral thromboembolic vascular disease and androgen deprivation therapy in asian prostate cancer patients. Sci. Rep. 2019, 9, 14231. [CrossRef] [PubMed]

9. Gandhi, J.; Afridi, A.; Vatsia, S.; Joshi, G.; Joshi, G.; Kaplan, S.A.; Smith, N.L.; Khan, S.A. The molecular biology of prostate cancer: Current understanding and clinical implications. Prostate Cancer Prostatic Dis. 2018, 21, 22-36. [CrossRef] [PubMed]

10. Benafif, S.; Kote-Jarai, Z.; Eeles, R.A.; Consortium, P. A review of prostate cancer genome-wide association studies (gwas). Cancer Epidemiol. Biomark. Prev. 2018, 27, 845-857. [CrossRef] [PubMed]

11. Fantus, R.J.; Helfand, B.T. Germline genetics of prostate cancer: Time to incorporate genetics into early detection tools. Clin. Chem. 2019, 65, 74-79. [CrossRef] [PubMed]

12. Kang, R.; Chen, R.; Zhang, Q.; Hou, W.; Wu, S.; Cao, L.; Huang, J.; Yu, Y.; Fan, X.G.; Yan, Z.; et al. Hmgb1 in health and disease. Mol. Aspects Med. 2014, 40,1-116. [CrossRef] [PubMed]

13. Kang, R.; Zhang, Q.; Zeh, H.J., III; Lotze, M.T.; Tang, D. Hmgb1 in cancer: Good, bad, or both? Clin. Cancer Res. Off. J. Am. Assoc. Cancer Res. 2013, 19, 4046-4057. [CrossRef] [PubMed]

14. Gnanasekar, M.; Thirugnanam, S.; Ramaswamy, K. Short hairpin rna (shrna) constructs targeting high mobility group box-1 (hmgb1) expression leads to inhibition of prostate cancer cell survival and apoptosis. Int. J. Oncol. 2009, 34, 425-431. [CrossRef] 
15. Li, T.; Gui, Y.; Yuan, T.; Liao, G.; Bian, C.; Jiang, Q.; Huang, S.; Liu, B.; Wu, D. Overexpression of high mobility group box 1 with poor prognosis in patients after radical prostatectomy. BJU Int. 2012, 110, E1125-E1130. [CrossRef]

16. Tripathi, A.; Shrinet, K.; Kumar, A. Hmgb1 protein as a novel target for cancer. Toxicol. Rep. 2019, 6, $253-261$. [CrossRef]

17. Vijayakumar, E.C.; Bhatt, L.K.; Prabhavalkar, K.S. High mobility group box-1 (hmgb1): A potential target in therapeutics. Curr. Drug Targets 2019, 20, 1474-1485. [CrossRef]

18. Sonpavde, G.; Agarwal, N.; Choueiri, T.K.; Kantoff, P.W. Recent advances in immunotherapy for the treatment of prostate cancer. Expert Opin. Biol. Ther. 2011, 11, 997-1009. [CrossRef]

19. Zhang, J.; Shao, S.; Han, D.; Xu, Y.; Jiao, D.; Wu, J.; Yang, F.; Ge, Y.; Shi, S.; Li, Y.; et al. High mobility group box 1 promotes the epithelial-to-mesenchymal transition in prostate cancer pc3 cells via the rage/nf-kappab signaling pathway. Int. J. Oncol. 2018, 53, 659-671. [CrossRef]

20. Gnanasekar, M.; Kalyanasundaram, R.; Zheng, G.; Chen, A.; Bosland, M.C.; Kajdacsy-Balla, A. Hmgb1: A promising therapeutic target for prostate cancer. Prostate Cancer 2013, 2013, 157103. [CrossRef]

21. Lin, C.W.; Chou, Y.E.; Yeh, C.M.; Yang, S.F.; Chuang, C.Y.; Liu, Y.F. A functional variant at the mirna binding site in hmgb1 gene is associated with risk of oral squamous cell carcinoma. Oncotarget 2017, 8, 34630-34642. [CrossRef] [PubMed]

22. Supic, G.; Kozomara, R.; Zeljic, K.; Stanimirovic, D.; Magic, M.; Surbatovic, M.; Jovic, N.; Magic, Z. Hmgb1 genetic polymorphisms in oral squamous cell carcinoma and oral lichen planus patients. Oral Dis. 2015, 21, 536-543. [CrossRef] [PubMed]

23. Wu, Y.L.; Chien, M.H.; Chou, Y.E.; Chang, J.H.; Liu, T.C.; Tsao, T.C.; Chou, M.C.; Yang, S.F. Association of egfr mutations and hmgb1 genetic polymorphisms in lung adenocarcinoma patients. J. Cancer 2019, 10, 2907-2914. [CrossRef] [PubMed]

24. Jiang, M.; Li, X.; Quan, X.; Li, X.; Zhou, B. Single nucleotide polymorphisms in hmgb1 correlate with lung cancer risk in the northeast chinese han population. Molecules 2018, 23, 832. [CrossRef]

25. Wang, Y.; Li, X.P.; Yin, J.Y.; Zhang, Y.; He, H.; Qian, C.Y.; Chen, J.; Zheng, Y.; Smieszkol, K.; Fu, Y.L.; et al. Association of hmgb1 and hmgb2 genetic polymorphisms with lung cancer chemotherapy response. Clin. Exp. Pharmacol. Physiol. 2014, 41, 408-415. [CrossRef]

26. Hu, W.; Liu, P.Y.; Yang, Y.C.; Chen, P.C.; Su, C.M.; Chao, C.C.; Tang, C.H. Association of hmgb1 gene polymorphisms with lung cancer susceptibility and clinical aspects. Int. J. Med. Sci. 2017, 14, 1197-1202. [CrossRef]

27. Huang, B.F.; Tzeng, H.E.; Chen, P.C.; Wang, C.Q.; Su, C.M.; Wang, Y.; Hu, G.N.; Zhao, Y.M.; Wang, Q.; Tang, C.H. Hmgb1 genetic polymorphisms are biomarkers for the development and progression of breast cancer. Int. J. Med. Sci. 2018, 15, 580-586. [CrossRef]

28. Lee, J.; Choi, J.; Chung, S.; Park, J.; Kim, J.E.; Sung, H.; Han, W.; Lee, J.W.; Park, S.K.; Kim, M.K.; et al. Genetic predisposition of polymorphisms in hmgb1-related genes to breast cancer prognosis in Korean women. J. Breast Cancer 2017, 20, 27-34. [CrossRef]

29. Yue, L.; Zhang, Q.; He, L.; Zhang, M.; Dong, J.; Zhao, D.; Ma, H.; Pan, H.; Zheng, L. Genetic predisposition of six well-defined polymorphisms in hmgb1/rage pathway to breast cancer in a large Han Chinese population. J. Cell. Mol. Med. 2016, 20, 1966-1973. [CrossRef]

30. Bao, G.; Qu, F.; He, L.; Zhao, H.; Wang, N.; Ji, G.; He, X. Prognostic significance of tag snp rs1045411 in hmgb1 of the aggressive gastric cancer in a chinese population. PLoS ONE 2016, 11, e0154378. [CrossRef]

31. Wang, B.; Yeh, C.B.; Lein, M.Y.; Su, C.M.; Yang, S.F.; Liu, Y.F.; Tang, C.H. Effects of hmgb1 polymorphisms on the susceptibility and progression of hepatocellular carcinoma. Int. J. Med. Sci. 2016, 13, 304-309. [CrossRef] [PubMed]

32. Wang, D.; Qi, X.; Liu, F.; Yang, C.; Jiang, W.; Wei, X.; Li, X.; Mi, J.; Tian, G. A multicenter matched case-control analysis on seven polymorphisms from hmgb1 and rage genes in predicting hepatocellular carcinoma risk. Oncotarget 2017, 8, 50109-50116. [CrossRef] [PubMed]

33. Wang, J.X.; Yu, H.L.; Bei, S.S.; Cui, Z.H.; Li, Z.W.; Liu, Z.J.; Lv, Y.F. Association of hmgb1 gene polymorphisms with risk of colorectal cancer in a Chinese population. Med. Sci. Monit. Int. Med. J. Exp. Clin. Res. 2016, 22, 3419-3425. [CrossRef] 
34. Lin, C.Y.; Wang, S.S.; Yang, C.K.; Li, J.R.; Chen, C.S.; Hung, S.C.; Chiu, K.Y.; Cheng, C.L.; Ou, Y.C.; Yang, S.F. Impact of gas5 genetic polymorphism on prostate cancer susceptibility and clinicopathologic characteristics. Int. J. Med. Sci. 2019, 16, 1424-1429. [CrossRef] [PubMed]

35. Epstein, J.I.; Egevad, L.; Amin, M.B.; Delahunt, B.; Srigley, J.R.; Humphrey, P.A.; Grading, C. The 2014 international society of urological pathology (isup) consensus conference on gleason grading of prostatic carcinoma: Definition of grading patterns and proposal for a new grading system. Am. J. Surg. Pathol. 2016, 40, 244-252. [CrossRef]

36. D'Amico, A.V.; Whittington, R.; Malkowicz, S.B.; Schultz, D.; Blank, K.; Broderick, G.A.; Tomaszewski, J.E.; Renshaw, A.A.; Kaplan, I.; Beard, C.J.; et al. Biochemical outcome after radical prostatectomy, external beam radiation therapy, or interstitial radiation therapy for clinically localized prostate cancer. JAMA 1998, 280, 969-974. [CrossRef] [PubMed]

37. Lin, C.Y.; Wang, S.S.; Yang, C.K.; Li, J.R.; Chen, C.S.; Hung, S.C.; Chiu, K.Y.; Cheng, C.L.; Ou, Y.C.; Yang, S.F. Genetic polymorphism and carbonic anhydrase 9 expression can predict nodal metastatic prostate cancer risk in patients with prostate-specific antigen levels $</=10 \mathrm{ng} / \mathrm{ml}$ at initial biopsy. Urol. Oncol. 2019, 37, 814.e9-814.e16.

38. Egevad, L.; Delahunt, B.; Srigley, J.R.; Samaratunga, H. International society of urological pathology (isup) grading of prostate cancer-An isup consensus on contemporary grading. APMIS Acta Pathol. Microbiol. Immunol. Scand. 2016, 124, 433-435. [CrossRef] [PubMed]

39. Hua, K.T.; Liu, Y.F.; Hsu, C.L.; Cheng, T.Y.; Yang, C.Y.; Chang, J.S.; Lee, W.J.; Hsiao, M.; Juan, H.F.; Chien, M.H.; et al. 3'utr polymorphisms of carbonic anhydrase ix determine the mir-34a targeting efficiency and prognosis of hepatocellular carcinoma. Sci. Rep. 2017, 7, 4466. [CrossRef]

40. Weng, W.C.; Chen, C.J.; Chen, P.N.; Wang, S.S.; Hsieh, M.J.; Yang, S.F. Impact of gene polymorphisms in gas5 on urothelial cell carcinoma development and clinical characteristics. Diagnostics 2020, 10, 260. [CrossRef]

41. International HapMap. The international HapMap project. Nature 2003, 426, 789-796. [CrossRef] [PubMed]

42. Song, W.; Tan, H.; Wang, S.; Zhang, Y.; Ding, Y. Association of high mobility group box protein b1 gene polymorphisms with pneumonia susceptibility and severity. Genet. Test. Mol. Biomark. 2019, 23, 3-11. [CrossRef] [PubMed]

43. Perdana, N.R.; Mochtar, C.A.; Umbas, R.; Hamid, A.R. The risk factors of prostate cancer and its prevention: A literature review. Acta Med. Indones. 2016, 48, 228-238.

44. Vickers, A.J.; Cronin, A.M.; Bjork, T.; Manjer, J.; Nilsson, P.M.; Dahlin, A.; Bjartell, A.; Scardino, P.T.; Ulmert, D.; Lilja, H. Prostate specific antigen concentration at age 60 and death or metastasis from prostate cancer: Case-control study. BMJ 2010, 341, c4521. [CrossRef]

45. Parkes, C.; Wald, N.J.; Murphy, P.; George, L.; Watt, H.C.; Kirby, R.; Knekt, P.; Helzlsouer, K.J.; Tuomilehto, J. Prospective observational study to assess value of prostate specific antigen as screening test for prostate cancer. BMJ 1995, 311, 1340-1343. [CrossRef]

46. Ahn, J.G.; Bae, Y.; Shin, D.; Nam, J.; Kim, K.Y.; Kim, D.S. Hmgb1 gene polymorphism is associated with coronary artery lesions and intravenous immunoglobulin resistance in kawasaki disease. Rheumatology 2019, 58, 770-775. [CrossRef] [PubMed]

47. Wu, H.H.; Liu, Y.F.; Yang, S.F.; Lin, W.L.; Chen, S.C.; Han, C.P.; Wang, H.L.; Lin, L.Y.; Wang, P.H. Association of single-nucleotide polymorphisms of high-mobility group box 1 with susceptibility and clinicopathological characteristics of uterine cervical neoplasia in taiwanese women. Tumour Biol. J. Int. Soc. Oncodev. Biol. Med. 2016, 37, 15813-15823. [CrossRef]

48. Yao, Y.; Guo, D.; Yang, S.; Jin, Y.; He, L.; Chen, J.; Zhao, X.; Chen, Y.; Zhou, W.; Shen, C. Hmgb1 gene polymorphism is associated with hypertension in han chinese population. Clin. Exp. Hypertens. 2015, 37, 166-171. [CrossRef]

49. Lee, K.; Chang, Y.; Song, K.; Park, Y.Y.; Huh, J.W.; Hong, S.B.; Lim, C.M.; Koh, Y. Associations between single nucleotide polymorphisms of high mobility group box 1 protein and clinical outcomes in korean sepsis patients. Yonsei Med. J. 2016, 57, 111-117. [CrossRef]

50. Hung, S.C.; Wang, S.S.; Li, J.R.; Chen, C.S.; Yang, C.K.; Chiu, K.Y.; Cheng, C.L.; Ou, Y.C.; Ho, H.C.; Yang, S.F. Effect of hmgb1 polymorphisms on urothelial cell carcinoma susceptibility and clinicopathological characteristics. Int. J. Med. Sci. 2018, 15, 1731-1736. [CrossRef] 
51. Li, X.Y.; Liang, C.H.; Yang, Y.J.; Liu, L.; Du, Y.J.; Liang, H.S.; Li, L.; Zhang, B.; Li, J.M.; Zhao, J.M. No association between hmgb1 polymorphisms and cancer risk: Evidence from a meta-analysis. Biosci. Rep. 2018, 38, BSR20180658. [CrossRef] [PubMed]

52. Li, J.H.; Liu, S.; Zhou, H.; Qu, L.H.; Yang, J.H. Starbase v2.0: Decoding mirna-cerna, mirna-ncrna and protein-rna interaction networks from large-scale clip-seq data. Nucleic Acids Res. 2014, 42, D92-D97. [CrossRef] [PubMed]

53. Han, P.Z.; Cao, D.H.; Zhang, X.L.; Ren, Z.J.; Wei, Q. Association between tp53 gene codon72 polymorphism and prostate cancer risk: A systematic review and meta-analysis. Medicine 2019, 98, e16135. [CrossRef] [PubMed]

54. Tan, S.H.; Petrovics, G.; Srivastava, S. Prostate cancer genomics: Recent advances and the prevailing underrepresentation from racial and ethnic minorities. Int. J. Mol. Sci. 2018, 19, 1255. [CrossRef]

(C) 2020 by the authors. Licensee MDPI, Basel, Switzerland. This article is an open access article distributed under the terms and conditions of the Creative Commons Attribution (CC BY) license (http://creativecommons.org/licenses/by/4.0/). 